\title{
Therapeutic effects of interferons in human viral infections
}

\section{Efectos terapéuticos de los interferones en las infecciones virales humanas}

Hebert Jair Barrales-Cureño ${ }^{1}$, César Reyes-Reyes ${ }^{1}$, Maximino Diaz-Bautista ${ }^{1}$, Adrián Gómez-de Jesús ${ }^{2}$, Salvador Chávez-Salinas ${ }^{3}$, Luis Germán López-Valdez ${ }^{4 *}$

${ }^{1}$ División de Procesos Naturales, Universidad Intercultural del Estado de Puebla. Calle Principal a Lipuntahuaca S/N; Lipuntahuaca, Huehuetla, Puebla, C.P. 73475.

${ }^{2}$ CONACYT-Facultad de Ciencias Agronómicas de la Universidad Autónoma de Chiapas. Carretera Ocozocoautla-Villaflores Km. 84.5. Apartado postal \# 78, C.P. 30470. Villaflores. Chiapas; México.

${ }^{3}$ División de Ingeniería en Biotecnología, Universidad Politécnica del Valle de Toluca, México. Carretera Toluca-Almoloya de Juárez Km. 5.6 Santiaguito Tlalcilalcali, Almoloya de Juárez, C.P. 50904.

${ }^{4}$ Laboratorio de Productos Naturales, Área de Química, Departamento de Preparatoria Agrícola. AP74 Oficina de correos Chapingo, Universidad Autónoma Chapingo, Km 38.5 Carretera México-Texcoco, Texcoco Estado de México, 56230.

*Corresponding author

E-mail address: 1germanlv@ taurus.chapingo.mx (L. G. López-Valdez)

Article history:

Received: 3 May 2018 / Received in revised form: 27 June 2018 / Accepted: 22 July 2018 / Published online: 1 October 2018.

https://doi.org/10.29267/mxjb.2018.3.4.19

\begin{abstract}
The interferon (IFN) is a cytokine produced by immunocompetent cells in response to various stimuli. Five types of IFNs are identified: alpha, beta, gamma, tau and omega 1. In particular, interferons inhibit viral replication directly by antiviral mechanisms, as they do so indirectly by amplifying immune responses to viral proteins. Likewise, they are also essential elements in clinical oncology. They are used in the treatment of chronic myelocytic and hairy cell leukemia, multiple myeloma, non-Hodgkin's lymphoma, melanoma, renal carcinoma, and Kaposi's sarcoma, as well as in the papilloma. They are also used in diseases of viral origin such as hepatitis B and C, acute respiratory syndrome, and HIV (experimentally in the latter), as well as in neurodegenerative diseases, including
\end{abstract}


multiple sclerosis or amyotrophic lateral sclerosis. The combination of interferons with other therapies is contributing to enhance its antiviral and antitumor activity. This work aims to present an updated reference on the use of interferons in the medical field.

Keywords: Cancer, hepatitis, HIV, therapeutic effect, type I interferons.

\section{RESUMEN}

El interferón es una citoquina producida por células inmunocompetentes en respuesta a diversos estímulos. Se identifican cinco tipos de IFN: alfa, beta, gama, tau y omega 1. Los interferones inhiben la replicación viral directamente por mecanismos antivirales e indirectamente amplificando las respuestas inmunes hacia las proteínas virales. Los interferones son imprescindibles en oncología clínica. Se utilizan para tratar leucemias tipo mielocítica crónica y de célula pilosa, mieloma múltiple, linfoma non-Hodgkin, melanoma, carcinoma renal, sarcoma de Kaposi y papilomas. Además, se utilizan en enfermedades de origen vírico como la hepatitis $\mathrm{B}$ y $\mathrm{C}$, síndrome agudo respiratorio, y se usan experimentalmente frente al VIH. Otra aplicación es en enfermedades neurodegenerativas como la esclerosis múltiple o esclerosis lateral amiotrófica. La combinación de los interferones con otras terapias está contribuyendo a potenciar su actividad antiviral y antitumoral. Los objetivos de este trabajo son presentar un referente actualizado del uso de los interferones en la clínica médica.

Palabras clave: Cáncer, efecto terapéutico, hepatitis, interferones tipo 1, VIH.

\section{INTRODUCTION}

Interferons (IFNs) are cytokines secreted by lymphocytes and macrophages previously infected by a virus (Shi-Fang et al, 2017). They represent a family of natural proteins, which show similar antiviral, anti-inflammatory, antiproliferative, antitumor and immunomodulating effects (Degrave and Mendonca-Lima, 2017; Kretschmer and LeeKirsch, 2017). In addition, interferons are a family of pleiotropic cytokines whose name was assigned because of their condition to inhibit viral replication (Ahmed and Casol, 2017). The actions of interferons include modulation of immune functions, including elevated phagocytosis and enhancement of the cytotoxic activity of $\mathrm{T}$ cells (Adams and Holland, 2009). After secretion, interferons bind to uninfected cells and mark them to secrete antiviral proteins. As part of the non-specific defense system, IFNs delay the spread of viral infections and increase the activity of existing leukocytes (Adams and Holland, 2009). Three types of major interferons have been identified in humans: alpha, beta and gamma. Alpha and beta interferons are type I, while type II is represented by interferon gamma. In particular, several cell types, including fibroblasts and macrophages, produce interferon beta. In general, type I interferons have the ability to increase nonspecific suppressor function of T cells (Palacios, 2004). Type I or classical interferons are divided into four classes: IFN $\alpha$, IFN $\beta$, IFN $\omega$ and IFN $\tau$. In particular, IFN $\alpha$ constitute a family of related proteins, which are encoded by different genes and synthesized by leukocytes, whereas IFN $\beta$ are a single protein encoded by a distinct gene, which is produced by 
fibroblasts. Type I interferons are important proteins in innate immunity. They occur in response to viral infection, while they have antiproliferative capacity, in addition to showing immunomodulatory effects and antitumor activity (Boxx and Cheng, 2016). Recently described, type III interferons are known as IFN- $\lambda s$, being that for humans they have been described as IFN $\lambda 1$, IFN- $\lambda 2$, and IFN- $\lambda 3$. These types of interferons are different from type I interferons in their structure and genetics, although they share biological properties and signaling pathways with type I interferons. The difference lies in the fact that the former bind to different membrane receptors (IFNLR and IL10R2). The class of interferons that has the greatest clinical utility is that related to interferon alpha, of which there are six different conformations: IFN alpha-2a, IFN alpha-2b, INF alpha-n3, INF alpha-n1, peg INF alpha-2a and peg INF alpha-2b (when used as medicine, the spell changes from alpha to alpha). In the two peg formations, the inert polyethylene glycol molecule binds to interferon. This addition extends the half-life of the drug, thereby achieving the application of one dose per week. Indications for alpha INF treatment include hairy cell leukemia as well as Kaposi's sarcoma related to Acquired Immune Deficiency Syndrome, chronic myeloid leukemia (alpha-2a) and chronic hepatitis B or C (alpha-2b) (Adams and Holland, 2009). The interferon beta is composed of two different formulations, beta-1a and beta-1b, which are reserved primarily for the treatment of severe multiple sclerosis (Arnason, 2005). A third such drug, gamma-1b INF, shows limited clinical application in the treatment of chronic granulomatous disease and in severe osteopetrosis (Adams and Holland, 2009). Interferon beta (IFN $\beta$ ) is a protein molecule that can be secreted by several types of human cells. It has the ability to modify the functions of lymphocytes and other cells. INF beta has the ability to deactivate some mechanisms that might be called "aggressive" in the immune system, which are responsible for damaging nerve tissue in multiple sclerosis. There are other applications for interferon beta in the field of medicine, based on its antiviral, antimicrobial and antitumor properties. Before, although the biological effects between the different classes are similar, IFN $\gamma$ or type II immune interferon does not share receptors with type I and type III interferons for its structure is different and its gene is located in a different chromosome from other. Different investigations conclude that IFN $\gamma$ potentiates the transcription of genes involved in immunomodulatory, antiviral, antitumor and antiproliferative activities (Parmar and Platanias, 2003). In the immune system, IFN $\gamma$ increases the cytotoxic and phagocytic activity of macrophages, while inducing the expression of major histocompatibility complex (MHC) class I and II molecules in dendritic cells and other antigen presenting cells. In addition, IFN $\gamma$ increases the development and differentiation of $\mathrm{T}$ helper cells 1 (Th1). Because of the above, IFN $\gamma$ acts predominantly in the control of bacterial, fungal, viral and parasitic infections (Schroder et al., 2004). Likewise, IFN $\gamma$ has a dual role, being both pro and anti-inflammatory, a condition that makes it a unique protein because its behavior depends on the environment in which it is found. New therapeutic strategies have been developed with the purpose of enhancing the immune response or replace the deficiency of the expression of its gene, being that the results in humans have proved to be successful. As a result, the recombinant IFN $\gamma$ is safe (Mata-Espinosa and HernándezPando, 2008). As previously mentioned, the objective of this review article is to indicate the use of type I interferons and their potential therapeutic effect against human diseases. 


\section{TYPES OF INTERFERONS}

The presentations available in our medium are interferon $\beta 1-\mathrm{a}($ Avonex $®$ and Rebif $®)$ and interferon $\beta$ 1-b (Betaferon $\left.{ }^{\circledR}\right)$. Both interferon $\beta 1-\mathrm{a}$ and $\beta$ 1-b are useful in the management of patients with multiple sclerosis chronic recurrent form, as both allow reducing the number of exacerbations. In particular, interferon $\beta 1$-a has been shown to delay the time to onset of symptoms of disability progression significantly. In turn, interferon $\beta 1-b$ has been proven useful during the treatment of multiple sclerosis as a secondarily progressive form. Table I shows some characteristics of the available products of interferons (Vaquero and Yecora, 2001).

Table I. Available interferons and approved therapeutic indications (Ramos-Belloa and Ramos-Niembrob, 2008).

\begin{tabular}{ll}
\hline \multicolumn{1}{c}{ Type } & \multicolumn{1}{c}{ Disease } \\
\hline Interferon $\boldsymbol{\alpha - 2 a}:$ & $\begin{array}{l}\text { Chronic hepatitis C, chronic myelocytic leukemia, hairy cell } \\
\text { leukemia, chronic Philadelphia chromosome-positive myelocytic } \\
\text { leukemia, Kaposi's sarcoma associated with human } \\
\text { immunodeficiency virus infection, non-Hodgkin's lymphoma. }\end{array}$ \\
Interferon $\boldsymbol{\alpha - 1 :}$ & $\begin{array}{l}\text { Chronic Hepatitis C } \\
\text { Chronic hepatitis C, chronic hepatitis B, condylomata acuminata, } \\
\text { follicular B cell lymphoma, hairy cell leukemia, Kaposi's }\end{array}$ \\
& sarcoma associated with human immunodeficiency virus \\
infection, malignant melanoma, non-Hodgkin's lymphoma
\end{tabular}

Varieties of cells have receptors for type I interferons. IFN $\alpha$ and IFN $\beta$ share and compete for the same sites in the cells, while gamma interferon occupies different receptors while also inducing similar cellular responses. Together, interferons have antiviral, antiinflammatory, and anti-tumor actions. Contrary to what was commonly thought, it is practically safe to consider that modifying the course of multiple sclerosis when using interferon beta, has no relation to its antiviral action, but rather to its anti-inflammatory action and probably its immunoregulatory actions. T-cell-derived interferon gamma has mainly proinflammatory action, which explains why the activity of multiple sclerosis worsens.

The use of interferon beta in the treatment of multiple sclerosis has been retrospectively recognized, with its anti-inflammatory and immunoregulatory action, together with its ability to inhibit the action of interferon gamma, represent the current bases in its application. In particular, it has been shown in in vitro cultures that the release of interferon 
gamma by mononuclear cells is reduced in patients treated with interferon beta. Patients with definitive diagnosis of multiple sclerosis, chronically recurrent or secondarily progressive, represent the best candidates for treatment with interferons. In this regard, the candidates suitable to start treatment are those patients who show two episodes of relapse in the previous two years. The treatment is applied on an outpatient basis, it being necessary to educate the patient for demonstrating a suitable adherence to the treatment (RamosBelloa and Ramos-Niembrob, 2008).

\section{IMPORTANCE OF THE TYPE OF INTERFERON}

The superiority of PEGylated interferon alpha 2-a on PEGylated interferon alpha 2-b was demonstrated by the controlled clinical studies carried out by the European Association for the Study of the Liver (EASL) and the American Association for the Study of Liver Diseases (AASLD) in 2008. Researchers found sustained viral responses from $66.0 \%$ to $68.7 \%$ with PEGylated IFN alpha 2-a, compared to responses in the range of $54.0 \%$ to $54.4 \%$ with Peglytated IFN alpha 2-b, registering a statistical significance of $p=0.008$. A clear superiority of PEGylated interferon alpha 2-a was also demonstrated with a Risk Ratio of 1.10 (95\% CI, 1.04, 1.19, p = 0.004), which was verified through the conduction of a meta-analysis. This test consists of eight studies with random assignment where the use of PEGylated IFN alpha 2-a (40 KD) with that of PEGylated IFN alpha b-2 (12 KD) was compared (Jacobsons et al, 2005).

\section{OTHER TYPES OF INTERFERONS}

Albuferon represents a recombinant $87.5 \mathrm{kDa}$ protein, which consists of an alpha interferon molecule to which an albumin molecule has been added. It is administered in at $900 \mu \mathrm{g}$ dosage schedule every two weeks, taking advantage of having a longer half-life and being applied over a longer period (twice month). Studies with this drug, along with ribavirin, have not shown a significant difference with respect to response rate when compared to standard PEGylated IFN alpha 2-a plus ribavirin treatment $(79.8 \%$ vs. $84.8 \%$ in the case of genotype 2 and $48.2 \%$ vs. $51.0 \%$ for genotype 1, respectively). As a result, the only advantage is its application every two weeks (Jacobsons et al, 2005). There is another type of interferon, which is the "consensus" (interferon alpha cons-1), whose molecular weight is 19,500 Daltons. This class consists of 166 amino acids, and its homology with interferon beta is $30 \%$. It is a cellular receptor of binding with high affinity with the type 1 of interferons. It has been observed that the daily dose of interferon consensus is cumulative so its treatment can be beneficial and effective. In the United States of America, interferon consensus is used in research studies aimed at the retreatment of patients who have not responded adequately to therapy, whose SVR rate ranges from $27.0 \%$ to $37.0 \%$ (CisnerosGarza, 2011).

\subsection{Interferon alpha-2a}

The prototypic drug denominated interferon alpha-2a is a biological response modifier that has the same function and indications as interferon alpha-2b. It is a natural protein 
produced by human lymphocytes between the first 4 and 6 hours after viral exposure. In its drug facet, it is prepared by the use of recombinant DNA technology, being available for use through disposable pre-filled syringes for subcutaneous administration. Interferon alpha- $2 \mathrm{a}$ acts on cancer cells through two mechanisms. Regarding the first mechanism, the drug increases or stimulates the immune system for the purpose of eliminating the antigens. As a second mechanism of action, it suppresses the growth of cancer cells. This type of interferon also shows antiviral activity. Indications for interferon alpha-2a include tricholeukemia, chronic hepatitis $\mathrm{C}$ infection, and malignant melanoma, conjunctival squamous cell carcinoma (Cruzado-Sánchez et al, 2017) while other uses are for hepatitis B and HIV-related Kaposi's sarcoma (Adams and Holland, 2009). Notwithstanding the foregoing, they do not meet the approved indication.

\section{APLICATIONS}

\subsection{Use of interferons in multiple sclerosis}

Multiple sclerosis is a demyelinating entity with autoimmune etiology, which affects myelin of the central nervous system. It also represents a neurological disease of unknown cause that intermittently affects the white matter (myelin) of the spinal cord and brain. As a result, nerve communication is delayed or interrupted, with myelin being replaced by hardened tissue plaques (sclerosis). Taking into consideration that this destruction occurs in different and multiple places, the disease has been named multiple sclerosis, and it causes a negative impact on whoever suffers it (Vaquero and Yecora, 2001). The number of patients who develop this disease is very high, being that there are about 2.5 million people with this disease in the world (350,000 people affected only in the United States of America). In general, the disease occurs in individuals with an average age of thirty years and in full productive stage in their life, where approximately $30.0 \%$ of them show moderate to severe disability. Symptoms of the disease are considered secondary to areas of inflammation and demyelination of the white matter in the brain and spinal cord. Likewise, the disease is presumed to be initiated by a process mediated by cellular immunity in which the Th1CD4+ cells are involved, which recognize a type of antigen in myelin of the nervous system. These cells pass the blood-brain barrier, initiating a specific immunological reaction that attracts other non-specific cells. Consequently, induction and release of cytokines, and antibody production, along with activation of microglia and astrocytes are presented. When new myelination takes place, it does not fully complete so that myelin, oligodendrocytes and axons are lost. This causes sequelae and the disease tends to progress. There are four forms of the disease according to their evolution in time and clinical point of view: chronic recurrent, secondary progressive, primary progressive and recurrent progressive. Even when patients (up to $80 \%$ ) may experience a variable course, the chronic recurrent form of the disease is present. The use of interferons modifies the course of the disease for the benefit of patients, so knowing their nature, indications and side effects becomes a priority. These compounds began to be used in the treatment of the disease considering that it was related to a viral infection and latent in the nervous system. At an early stage, no distinction was made between the type of interferon to be used and the route of administration of element, which could be systemic or intrathecal. Subsequently, a series of pilot studies were conducted in a few patients in the 1980s, mostly uncontrolled, where 
the interferon alpha, beta and gamma classes were used. These studies demonstrated that gamma interferon should not be used in patients with multiple sclerosis (Palacios, 2004).

In Spain, three commercial brands of IFN beta have been approved: Betaferon ${ }^{(I F N ~ b e t a ~}$ 1b; dosage: $0.25 \mathrm{mg} / 48 \mathrm{~h}$; mean of administration: subcutaneous), Avonex ${ }^{\circledR}$ (dosage: 30 $\mu \mathrm{g}$ once a week; mean of administration: intramuscular) and Rebif® (both are IFN beta 1a; Dosage: $22 \mu \mathrm{g} 3$ times per week or $44 \mu \mathrm{g} 3$ times per week; means of administration: subcutaneous), with the first drug being indicated both in the relapsing remitting form (RR) and secondary progression (SP), whereas the other two drugs are only indicated in the RR form (Vaquero and Yecora, 2001).

\subsection{Intralesional Interferon (IV, C)}

Natural or recombinant interferon which is used in the treatment of VGs and has been administered systemically (e.g., subcutaneously at a distal site or IM) and intralesional (e.g., injected into warts), while systemic interferon is not effective. The efficacy and relapses of intralesional interferon are comparable to other treatment modalities. Interferon works because of its antiviral and/or immunostimulating effect. Nevertheless, interferon treatment is not recommended for routine use because of the inconvenience of its application means, the need for frequent visits to the clinic, and the association of its use with the frequent occurrence of systemic adverse effects on the patient (Squiquera, 2006).

\subsection{Acquired Immunodeficiency Virus and JC virus}

The cytokines interleukin-12 (IL-12), IL-4, IL-6, IL-16 and interferon gamma (IFN- $\gamma$ ) determine whether an adaptive immune response type Th1 or Th2 predominates. In particular, the Th1 response coordinates the action of the immune system against infections by intracellular germs, such as HIV-1, whereas the Th2 response regulates immunity against extracellular pathogens by stimulating antibody secretion and observes what predominates in patients infected with HIV-1, especially those who are in advanced stages of the disease (Altfeld et al, 2000). Other cytokines, such as tumor necrosis factor-alpha (TNF- $\alpha$ ) and interferons (IFN) also affect HIV-1 replication (Montoya et al, 2006). In recent years, some soluble factors (defensins, chemokines and ribonucleases) that are secreted by different cells during the immune response and that have antiviral activity (Montoya et al, 2006) have gained importance in the process of natural resistance to HIV-1 infection. This has allowed to propose a new model of anti-HIV-1 immunity that involves the suppression of viral replication without eliminating the infected cell, enhancing other specific anti-HIV-1 cellular mechanisms. These soluble factors include CCL5 (RANTES), CCL3 (MIP1- $\alpha$ ) and CCL4 (MIP1 $\beta$ ) chemokines, stromal cell-derived factor 1 (SDF1 or CXCL12), antiviral factor derived from CD8 + T lymphocytes, Type I and II interferons, and leukemia inhibitory factor. Likewise, lysozyme and RNase associated with human chorionic gonadotrophin, alloantigen-induced soluble factor (ASF), beta defensins, leukocyte secreted protease inhibitor and other more recently defined factors such as proteins with TRIM motifs (Zapata et al, 2006), which function as cellular mechanisms. Neurovirology is the branch of medical science dedicated to the study of viral agents that affect the nervous system. The JC virus is a DNA-type neurotropic virus that causes progressive multifocal leukoencephalopathy (PML) (Cedeno et al, 2006). It is recognized 
that $80.0 \%$ of the general population produces antibodies directed against the JC virus. Notwithstanding the above, seroconversion occurs as a reflection of asymptomatic disease. The incidence of Progressive Multifocal Leukoencephalopathy (PML) cases has been increasing in parallel with that of the outbreak of the AIDS epidemic, along with the era of transplant immunosuppression and antitumor therapy. PML is an attractive disease for its study due to the rapid evolution of the cognitive, motor and visual deterioration of the patient, as well as to the sudden death of the patient. Also, interest in the disease stems from the absence of treatment, which also translates into the exploration and development of effective and novel forms of therapy (Cedeno et al, 2006).

\subsection{Human Papilloma Virus}

Treatment of Human Papilloma Virus (HPV) has not been adequately established. There are multiple therapeutic trials both nationally and internationally, including cryotherapy, laser, electro surgery and the use of biomolecules, such as interferon. The interferon, a biological agent of recognized antiviral, antiproliferative and immunomodulatory activity, is an important weapon in the treatment of many viral diseases. Currently, interferon comes in the form of bulbs, creams and tablets, the latter having advantages over other presentations due to their manufacturing costs. Human Papilloma viruses cause alterations in the squamous epithelium, being that several types are related to premalignant and malignant lesions of the uterine cervix. Currently, various types of treatment have been used in the world in order to eliminate human papilloma infection. During the conduct of research works in this respect, the usefulness of interferon as an alternative treatment for HPV was evaluated through a prospective longitudinal study with 72 patients diagnosed histologically. Thirty-six individuals were asked to ingest for 24 weeks a homeopathic sublingual tablet of $100 \mathrm{mg}$ of recombinant interferon alpha, while the rest of the population was classified as the control group without interferon alpha. As a result, a high cyto-colposcopic correlation was observed, so the response to treatment was considered highly acceptable over the study group (Torriente and Martínez, 2002). After nearly a decade of combined treatment using PEG IFN- $\alpha$ and ribavirin, new HCV-specific drugs have recently been developed, which offer a promising future for patients with chronic hepatitis $\mathrm{C}$ infected with genotype 1 (Saludes et al, 2011). 50.0\% of them have successfully responded to standard therapy with PEGylated interferon alpha and ribavirin, with newly approved protease inhibitors being administered with these two drugs (Saludes et al, 2011).

\subsection{Interferon in chronic infection with hepatitis B virus}

Hepatitis B is one of the most common viral infections in the world. It is estimated that about 250-350 million individuals have chronic infection, representing a population that is at risk of developing liver cirrhosis or hepatocellular carcinoma (Konerman et al, 2016; Ramos-Belloa and Ramos-Niembrob, 2008). The first studies on the use of interferon in hepatitis B were conducted in the mid-1970s with the use of interferon preparations produced in leukocyte or fibroblast cultures (Ortega and Garzón, 2009). Today, large-scale interferons are produced by genetic engineering techniques, including preparations, to which polyethylene glycol (PEGylated interferon) has been added, an element that increases its half-life and response rate. The goal in short-term treatment is to decrease viral replication, which would clinically lead to the prevention of progression to cirrhosis or 
hepatocellular carcinoma and, thus, increasing the survival rate. Treatment with IFN Alpha, which was approved in 1992, nowadays represents one of the first-line forms to treat chronic hepatitis B. The treatment of hepatitis B with interferon has the advantage of not being for life, where this compound is not associated with resistance to the treatment itself. Currently, PEGylated IFN $\alpha-2 \mathrm{a}$ and IFN $\alpha-2 b$ are available, elements leading to the fact that one dose per week is only required, which translates into greater efficacy in individuals with this disease (Hui et al, 2005). IFN- $\alpha$ is most studied and the only type of IFN approved for treatment of hepatitis B in most countries. The antiviral effects of IFN- $\alpha$ depend on its binding to specific receptors, which then triggers a series of intracellular success including activation of $2^{\prime}, 5^{\prime}$-oligoadenylate synthetase (Konerman et al, 2016). The therapeutic options in chronic hepatitis B have increased and currently six treatments are authorized: adefovir, entecavir, lamivudine, pegylated interferon $\alpha$ (PEG-IFN $\alpha$ ), standard interferon (IFN $)$, and telbivudine (García et al, 2008).

\subsection{Interferon in chronic infection with hepatitis $C$ virus}

Hepatitis $\mathrm{C}$ is an important health problem; thus, the diagnosis of the disease in high-risk groups is essential because of the likelihood that it may develop the disease in a chronic way. Some examples are cirrhosis, decompensation of cirrhosis, an eventual need for a liver transplant or the development of hepatocellular carcinoma. Presently, the Established Elective Treatment (EET) includes PEGylated interferon and ribavirin, compounds that show a response rate close to $57.0 \%$ in the case of genotype 1 , the most prevalent form in Mexico. It is known that between $30.0 \%$ and $60.0 \%$ of the population in the country does not show a sustained viral response (SVR) or cure (Cisneros-Garza, 2011). In 2002, the National Institute of Health of the United States of America reached a consensus regarding hepatitis $\mathrm{C}$, in which it was determined that the use of PEGylated interferon (INF-PEG), together with ribavirin (another antiviral) in a dose of $1000 \mathrm{mg}$ in patients weighing less than $75 \mathrm{~kg}$ and a dose of $1200 \mathrm{mg}$ in patients weighing more than $75 \mathrm{~kg}$ for 48 weeks for genotypes 1 and 4, would represent the EET for the management of the disease (CisnerosGarza, 2011). In the case of genotypes 1 and 3, the doses would be $800 \mathrm{mg}$ for 24 weeks. This treatment was ratified when the guidelines for diagnosis and treatment of hepatitis $\mathrm{C}$ for 2009, as well as the guidelines of the European Association for the Study of the Liver (EASL), were updated for 2011 (Cisneros-Garza, 2011). At present, about $50.0 \%$ of the world population has not responded to EET (PEGylated interferon and ribavirin). Since it is the only available therapy so far, it is necessary to optimize it for the implementation of the strategies that will be discussed below. Hepatitis $\mathrm{C}$ virus infection has been compared to a viral time bomb. According to some estimates, approximately 180 million people have been infected worldwide, of which about 130 million show chronic infection and therefore are at risk of developing liver cirrhosis or hepatocellular carcinoma. Attempts have been made in the form of monotherapy for six months, which showed a response rate of $10.0 \%$ to $15.0 \%$, representing a ratio that has risen to the range of $20.0 \%$ to $25.0 \%$ with administration for 12 to 18 months. Nevertheless, the combination of PEGylated IFN $\alpha-2 b$ and ribavirin is currently the first-line therapy for patients with chronic hepatitis $\mathrm{C}$. The combination has been shown to reduce the morbidity and mortality rates of patients receiving this treatment (Morillas et al, 2017; Ramos-Bellos and Ramos-Niembrob, 2008). 
Interferon against malignant diseases. The potential of interferon in cancer management was initially explored in animal models of leukemia by Friend and Rauscher (Ward and Kugelmas, 2005), and subsequently confirmed one year later in experimental animals challenged with tumor cells (Gresser et al, 1969). Without being able to go into detail because of the large extent of the literature, the antiproliferative properties of interferon have been tested, with varying degrees of success, in a variety of malignant processes. Regarding that, their use has been approved in several of these processes, either as monotherapy or in combination therapy, among them are hairy cell leukemia (Goodman et al, 2003; Robak, 2006); melanoma (Hurley and Chapman, 2005; Sabel and Sondak, 2003; Gray et al, 2002); and non-Hodgkin's lymphoma (Reiser and Diehl, 2002; Solal-Céligny, 2002). Also, cutaneous T-cell lymphoma (Olsen, 2003); multiple myeloma (Dummer et al, 2003; Mellstedt et al, 1991); chronic myelocytic leukemia; and Kaposi's sarcoma (Guilhot et al, 2007; Krown et al, 2002; Aversa et al, 2005), among others.

\subsection{Interferon in miscellaneous conditions}

Several interferon preparations have been used topically, intralesionally or intramuscularly, showing relative success in other conditions. Among them are human papilloma virus infection at various sites (Gerein et al, 2005); condyloma acuminata; Sjögren's Syndrome (Cummins et al, 2003); Churg-Strauss Syndrome; and Behçet's disease (Kotter et al, 2003; Calguneri et al, 2003).

\section{CONCLUSIONS}

The availability of different types of interferons has allowed the realization of a wide range of clinical treatments in humans. These drugs are used in the treatment of oncohaematological diseases (leukemias, lymphomas), melanoma, carcinoid tumors, mycosis fungoides and renal carcinoma. Their effectiveness has been demonstrated against viral diseases, tumors and neurodegenerative diseases. However, due to the multiple effects it induces in a cell, it is not surprising that we are still far from managing these molecules optimally, taking into account the differences that occur in gene expression level among individuals. For the above reasons, it is sought to regulate the action of enzymes induced by IFNs, such as PKR, being that in recent studies its activation has been observed in several pathologies, such as Alzheimer's, Parkinson's, Huntington's and Fanconi's Anemia. Knowing the precise mechanisms of induction of apoptosis by the PKR kinase and other proteins induced by IFNs, will serve to improve the therapeutic treatments performed with the IFNs. Likewise, prostate cancer has been correlated with RNase L activation. In this way, a new era has started in clinical medicine, which is aimed at activating or inhibiting the action of genes induced by IFNs, in order to optimize the therapeutic application of such powerful, biological molecules. Knowledge of the broad spectrum of genes induced by interferons by biochip techniques, and delving into the functional implications of each of them, will serve in the future to rationalize the therapies. All these clinical applications will be based, as it has been happening until now, on the advance of basic and clinical science. 


\section{ACKNOWLEDGEMENTS}

This work was supported by the "Programa para el Desarrollo Profesional Docente" PRODEP-Mexico of the project 2017-2018 of Hebert Jair Barrales-Cureño PhD of the Universidad Intercultural del Estado de Puebla.

\section{CONFLICT OF INTEREST}

All contributing authors declare no conflict of interest.

\section{REFERENCES}

Adams M, \& Holland N. 2009. Farmacologia para enfermería. Un enfoque fisiopatológico. Pearson/Prentice Hall, Madrid, Esp. pp. 931.

Ahmed D. \& Cassol E. 2017. Role of cellular metabolism in regulating type I interferon responses: Implications for tumour immunology and treatment. Cancer Letters. 409: 20-29.

Altfeld M., Addo M. M., Kreuzer K. A. 2000. T(H)1 to T(H)2 shift of cytokines in peripheral blood of HIV infected patients is detectable by reverse transcriptase polymerase chain reaction but not by enzyme-linked immunosorbent assay under nonstimulated conditions. Journal of Acquired Immune Deficiency Syndromes. 23: 287-94.

Arnason B. G. 2005. Long-term experience with interferon beta-1b (Betaferon) in multiple sclerosis. Journal of Neurology. 252: 28-33.

Aversa S. M., Cattelan A. M., Salvagno L., Crivellari G., Banna G., Trevenzoli M., Chiarion-Sileni V., Monfardini S. 2005. Treatments of AIDS-related Kaposi's sarcoma. Critical Reviews in Oncology Hematology. 53: 253-265.

Boxx M. G. \& Cheng G. 2016. The Roles of Type I Interferon in Bacterial Infection. Cell Host \& Microbe. 19: 760-769.

Çalgüneri M., Öztürk M. A., Ertenli I., Kiraz S., Apras S., Ozbalkan Z. 2003. Effects of interferon alpha treatment on the clinical course of refractory Behçet's disease: an open study. Annals of the Rheumatic Diseases. 62: 492-493.

Cedeno F., Penalva de Oliveira A. C., Vidal J. E., Trujillo J. R. 2006. Virus neurotrópicos: el virus JC y la leucoencefalopatía multifocal progresiva. Revista Mexicana de Neurociencia. 7: 46-54.

Cisneros-Garza L. E. 2011. Nuevos avances en el manejo de la hepatitis C. Salud Pública de México. 53: 52-60.

Cummins M. J., Papas A., Kammer G. M., Fox P. C. 2003. Treatment of primary Sjögren's syndrome with low-dose human interferon alfa administered by the oromucosal route: combined phase III results. Arthritis \& Rheumatology. 49: 585-593. 
Cruzado-Sánchez D., Salas-Diaz M., Tellez W. A., Alvarez-Matos S. E., Serpa-Frías S. 2017. Interferon alpha-2a as alternative treatment for conjunctival squamous cell carcinoma. Archivos de la Sociedad Española de Oftalmología. 92: 539-542.

Degrave W. M. S. \& Mendonca-Lima L. 2017. Current Developments in Biotechnology and Bioengineering. Human and Animal Health Applications. 51-70.

Dummer R., Kempf W., Schmid M. H., Haffner A., Burg G. 2003. Therapy of cutaneous lymphoma-current practice and future developments. Onkologie. 26: 366-372.

García B. L., González M. F., Moreno O. R. 2008. Interferon in hepatitis B. Enfermedades Infecciosas y Microbiología Clínica. 26: 19-31.

García M. J. A. 2014. Tratamiento actual de la esclerosis múltiple. Medicina Clínica. 143: 19-22.

Gerein V., Rastorguev E., Gerein J., Jecker P., Pfister H. 2005. Use of interferón alpha in recurrent respiratory papillomatosis: 20-year follow-up. Annals of Otology, Rhinology \& Laryngology. 114: 463-471.

Goodman G. R., Bethel K. J., Saven A 2003. Hairy cell leukemia: an update. Current Opinion in Hematology. 10: 258-266.

Gray R. J., Pockaj B. A., Kirkwood J. M. 2002. An update on adjuvant interferon for melanoma. Cancer Control. 9: 16-21.

Gresser I., Bourali C., Levy J. P., Fontaine-Brouty-Boye D., Thomas M. T. 1969. Increased survival in mice inoculated with tumor cells and treated with interferon preparations. Proceedings of the National Academy of Sciences. 63: 51-57.

Guilhot F., Roy L., Martineua G., Guilhot J., Millot F. 2007. Immunotherapy in chronic myelogenous leukemia. Clinical Lymphoma Myeloma and Leukemia. 7: 64-70.

Hui A. Y., Chan H. L., Cheung A. Y. 2005. Systematic review: treatment of chronic hepatitis B virus infection by pegylated interferón. Alimentary Pharmacology \& Therapeutics. 5: 519-528.

Hurley K. E. \& Chapman P. B. 2005. Helping melanoma patients decide whether to choose adjuvant high-dose interferon-alpha2b. The Oncologist. 10: 739-742.

Jacobsons I. M., González A., Ahmed F., Lebovics E., Min D. A., Bodenheimer C. H., Esposito P. E., Brown S. R., Brau N., Klion M. F., Tobias H., Bini J. E., Brodsky N., Cerulli A. M., Aytaman A., Gardner W. P., Geders M. J., Spivack E. J., Rahmin G. M., Berman H. D., Ehrlich J., Russo W. M., Chait M., Rovner D., Edlin R. B. 2005. A randomized trial of pegylated interferon alpha- $2 \mathrm{~b}$ plus ribavirin in the retreatment of chronic hepatitis C. The American Journal of Gastroenterology. 100: 2453-2462. 
Kretschmer S. \& Lee-Kirsch M. A. 2017. Type I interferon-mediated autoinflammation and autoimmunity. Current Opinion in Immunology. 49: 96-102.

Krown S. E., Li P., Von Roenn J. H., Paredes J., Huang J., Testa M. A. 2002. Efficacy of low-dose interferon with antiretroviral therapy in Kaposi's sarcoma: a randomized phase II AIDS clinical trials group study. Journal of Interferon \& Cytokine Research. 22: 295-303.

Konerman A. M. \& Lok S. A. 2016. Interferon treatment for Hepatitis B. Clinics in Liver Disease. 20: 645-665.

Kötter I., Günaydin I., Zierhutm M., Stùbiger N. 2003. The use of interferon alpha in Behçet's disease: Review of the literatura. Seminars in Arthritis and Rheumatism. 33: 320335.

Lin O. S. \& Keeffe E. B. 2001. Current treatment strategies for chronic hepatitis B and C. Annual Review of Medicine. 52: 29-49.

Mata-Espinosa D. A. \& Hernández-Pando R. 2008. Interferón gamma: aspectos básicos, importancia clínica y usos terapéuticos. Revista de Investigación Clínica. 60: 421-431.

Mellstedt H., Osterborg A., Bjorkholm M., Bjoreman M., Brenning G., Gahrton G., Grimfors G., Gyllenhammar H., Hast R., Juliusson G., Jaurnmark M., Killander A., Kimby E., Lerner R., Merk K., Ohrling M., Simmonsson B., Smedmyr, Stalfelt A. M., Strander H., Svedmyr E., Udean A. M., Montoya Guarín C. J., Moreno Fernández M. E., Rugeles López M. T. 2006. Reacciones y alteraciones del sistema inmune durante la infección por el VIH1. Infectio. 10: 250-265.

Morillas R. M., Masnou H., Ardévolb M., López D. 2017. Role of ribavirin in interferón free therapy for the treatment of hepatitis C virus. Gastroenterología y Hepatología. 40: 699-708.

Olsen E. A. 2003. Interferon in the treatment of cutaneous T-cell lymphoma. Dermatology Therapy. 16: 311-321.

Ortega Q. R. \& Garzón O. M. A. 2009. Tratamiento de la hepatitis B. Revista Colombiana de Gastroenterologia. 24: 21-32.

Ostrowski S. R., Gerstoft J., Pedersen B. K., Ullum H. 2003. Impaired production of cytokines is an independent predictor of mortality in HIV-1-infected patients. AIDS. 17: 521-530.

Palacios L. 2004. Interferones: Su lugar en el armamentario terapéutico de la esclerosis múltiple. Bogotá, Colombia, ACN. Vol. 4. 
Parmar S. \& Platanias L. C. 2003. Interferons: mechanisms of action and clinical applications. Curr Opin Oncol. 15: 431-439.

Ramos-Belloa D. \& Ramos-Niembrob F. 2008. Interferón: 50 años después (1957-2007). Gaceta Médica de México. 144: 55-65.

Reiser M. \& Diehl V. 2002. Current treatment of follicular non-Hodgkin's lymphoma. European Journal of Cancer. 38: 1167-1172.

Robak T. 2006. Current treatment options in hairy cell leukemia and hairy cell leukemia variant. Cancer Treatment Reviews. 32: 365-376.

Schroder K., Hertzong P. J., Ravasi T., Hume D. A. 2004. Interferon- $\gamma$ : an overview of signals, mechanisms and functions. Journal of leukocyte biology. 75: 163-189.

Sabel M. S. \& Sondak V. K. 2003. Is there a role for adjuvant high-dose interferon-alpha$2 \mathrm{~b}$ in the management of melanoma?. Drugs. 63: 1053-1058.

Saludes V. M., Ausina V. R., Martró E. C. 2011. Posibilidades actuales para predecir la respuesta a la terapia en pacientes con hepatitis $\mathrm{C}$ crónica por el genotipo 1 del virus de la hepatitis C. Enfermedades Infecciosas y Microbiología Clínica. 29: 51-58.

Shi-Fang L., Fu-Rong Z., Jun-Jun S., Yin-Li X., Hui-Yun C., Yong-Guang Z. 2017. Interferon-omega: Current status in clinical applications. International Immunopharmacology. 52: 253-260.

Solal-Céligny P. 2002. Increasing treatment options in indolent non-Hodgkin's lymphoma. Seminars in Oncology. 29: 2-6.

Squiquera L. 2006. Virus de papiloma humano. Revisión e indicaciones terapéuticas. Revista Argentina de Dermatología. 87: 28-41.

Tezano S. A. P. 2006. Interferones y vacunas como control de enfermedades prevalentes. Instituto de España, Real Academia Nacional de Farmacia. 1-86.

Torriente H. B. \& Martínez R. V. 2002. Aplicación del interferón en el tratamiento de la infección por virus del papiloma humano. Revista Cubana de Obstetricia y Ginecología. 38: 174-177.

Vaquero G. M. D. \& Yecora N. M. G. 2001. Uso terapéutico del interferón beta en el Insalud. Información Terapéutica del Sistema Nacional de Salud. 25: 9-16.

Ward R. P. \& Kugelmas M. 2005. Using pegylated interferon and ribavirin to treat patients with chronic hepatitis C. American Family Physician. 72: 655-662.

Zapata W., Montoya C. J., Rugeles M. T. 2006. Factores solubles con actividad inhibitoria contra el virus de la inmunodeficiencia humana tipo 1. Biomédica. 26: 451-466. 